\title{
The development of telemedicine programs in Sub-Saharan Africa: Progress and associated challenges
}

\author{
Joana Eva Dodoo ${ }^{1,1} \cdot$ Hosam Al-Samarraie ${ }^{2,3}$ (D) $\cdot$ Ahmed Alsswey $^{4}$ \\ Received: 6 August 2021 / Accepted: 18 November 2021 / Published online: 25 November 2021 \\ (c) The Author(s) 2021
}

\begin{abstract}
Monitoring the progress of telemedicine use in Sub-Saharan Africa (SSA) countries has received a considerable attention from many health organizations and governmental agencies. This study reviewed the current progress and challenges in relation to the development of telemedicine programs in SSA. The results from reviewing 66 empirical studies revealed an unbalanced progress across SSA countries. Further, technological, organisational, legal and regulatory, individual, financial, and cultural aspects were identified as the major barriers to the success of telemedicine development in SSA. This study reported the current trends in telemedicine application, as well as highlighting critical barriers for consideration by healthcare decision makers. The outcomes from this study offer a number of recommendations to support wider implementation and sustainable usage of telemedicine in SSA.
\end{abstract}

Keywords Telemedicine $\cdot$ Sub-Saharan Africa $\cdot$ Healthcare readiness

\section{Introduction}

The use of telemedicine systems in healthcare provision has received wide endorsement from the policy makers, medical practitioners and researchers. Monitoring the developing of telemedicine programs has received a wide attention recently in most developed countries. This can be due to the effectiveness of telemedicine in facilitating rapid access to specialists, diagnosis, treatment, and prevention of injuries and diseases [1,2]. It is useful particularly in emergency response situations such as the recent COVID-19 pandemic [3]. Telemedicine was instrumental in the fighting of major epidemic outbreaks such as the severe respiratory syndrome epidemic (SARS) in Taiwan, H1N1 and H7N9 pandemic

Hosam Al-Samarraie

h.alsamarraie@leeds.ac.uk; myclasy@gmail.com

1 College of Distance Education, Department of Business Studies, University of Cape Coast, Cape Coast, Ghana

2 School of Design, University of Leeds, Leeds, UK

3 Centre for Instructional Technology \& Multimedia, Universiti Sains Malaysia, Penang, Malaysia

4 Department of Multimedia Technology, AL-Zaytoonah University of Jordan, Amman, Jordan influenza in China, and Middle-East respiratory syndrome (MERS) coronavirus epidemic [4]. Behar, et al. [5] reviewed the global uptake of telemedicine in the wake of the COVID19 global pandemic. The authors demonstrated how various countries across the globe have deployed telemedicine as an efficient route for testing, remote monitoring of patients with mild COVID-19 symptoms, contact tracing and symptom triage.

Telemedicine programs are not new to healthcare organizations in SSA. These programs have supported the strengthening of healthcare, patient and professional health-related education, surveillance and prevention of diseases in SSA [6]. They were effective in the fighting of the Ebola virus disease in some parts of Africa [4]. Recent studies suggest a renewed effort towards the implementation of telemedicine systems in SSA, in particular as an alternative healthcare route in the era of COVID-19 crises [5,7]. This was possible due to the wide usage of mobile telecommunication systems in SSA countries. Holst, et al. [8] commented that telemedicine systems can be a potential gamechanger in healthcare provision in SSA. According to them, 41 countries in SSA have in place national digital health strategies and architectures (NDHSA). It is projected that the mobile telephone connections of 816 million as at 2019 in SSA will increase to 1.05 billion by 2025 [9], thereby making it easier for a wider use of telemedicine applications. 
Although the above studies have shown how various programs of telemedicine can support the effort to curtail the negative impact of COVID-19 in SSA, they do not indicate the progress and the extent made with regard to the implementation of telemedicine in these countries. For example, Edoh, et al. [10] attempted to review telemedicine system user satisfaction in two West African countries. The authors reported a major lack of studies on telemedicine progress to serve as a baseline for indicating users' satisfaction with telemedicine services. Adebayo, et al. [11] limited their study to teleneurology practice and infrastructural preparedness in SSA, which limits the extent to which various countries in SSA have made progress in terms of telemedicine implementation.

In addition, previous literature has attempted to describe telemedicine uptake in a piecemeal manner or limited to specific telemedicine services, whereas differences were reported among SSA countries. This gap presents an opportunity to investigate progress in the development of telemedicine programs and associated challenges in SSA. It is anticipated that the outcomes from this review will offer timely directions to policy makers on the extent of telemedicine implementation for strategic regional collaborations. It will also determine the various phases of telemedicine implementation that can potentially assist in addressing the perceived repetitions of certain telemedicine systems observed in SSA countries such as South Africa [6, 12]. This study is important in that it offers a holistic view of the extent of telemedicine progress and offers a pathway for continuity and advancement of telemedicine systems in SSA.

\section{Methodology}

This study was designed to answer two research questions: "What is the current progress in the use and adoption of telemedicine programs in SSA countries?" and "What are the associated challenges of implementing telemedicine programs in these countries?" We adapted the Preferred Reporting Items for Systematic Reviews and Meta-Analyses (PRISMA) guidelines [13] to answer these questions. PRISMA was used in this study because it offers detailed and step-by-step instructions for identifying and evaluating previous studies in relation to the current research area $[14,15]$.

\subsection{Articles search and inclusion criteria}

This study was conducted to provide a roadmap for healthcare decision makers to understand the current development of telemedicine programs in SSA. We used quotation marks in the search process in order to produce the desired intersection. Key words used include: ("progress" OR "factors") AND ("affect' OR "impact" OR "influence" OR "utilized" OR "adopt" OR "implement") AND ("telemedicine" OR "e-health" OR "telehealth" OR "eHealth readiness" OR "electronic health" OR "electronic health record") AND ("Sub-Saharan African countries" OR "African countries" OR "SSA countries" OR "Community of Sahel-Saharan States" OR "Economic Community of West African States" OR "Economic Community of Central African States" OR "East African Community" OR "Southern African Development Community" OR "the Country name"). The retrieved papers were peer-reviewed and published in journals, conference proceedings/chapters, or university repositories. During our search of the literature, there were no restrictions placed on the language, data, or publication status of the articles. We only included empirical studies and governmental reports. The date of publication was not limited in this review.

\subsection{Screening and coding of the articles}

We were able to identify/filter the relevant and non-relevant studies for this review. We used specific keywords to retrieve articles that can be used to answer the research questions. A total of 7840 studies dies were retrieved from multiple databases such as PubMed, IEEE Xplore Digital Library, Cochrane, ProQuest, Web of Science, Scopus, Global Health, and Google Scholar. A total of 230 studies were duplicates (which we removed). Further, we screened all the titles and abstracts related to the search keywords. After applying the inclusion criteria discussed above, a total of 192 studies were finalized for full text review. This led to further exclusion of 126 articles, either because the articles covered theoretical and conceptual aspects. The finalized 66 studies were then subjected to full text review to examine the progress and challenges of telemedicine programs in SSA countries. The identified challenges (based on the country where the research was conducted) were placed into six categories/dimensions: organisational, technological, financial, individual, culture, and legal barriers. Challenges identified in the final list of articles were categorized using an item-focused coding approach due to its heterogeneity across disciplines. The barriers were placed under the technological dimension if they were related to information system and connectivity software. The barriers that were placed under the financial dimension were those related to financial resource and operational cost of telemedicine. The barriers that were placed under the individual dimension were related to users' experience, knowledge, and awareness of telemedicine systems. The barriers related to certain social constraints and traditional beliefs inside the community were placed under the cultural dimension. Lastly, the barriers that were related to the policies, legislation, standard governing confidentiality and privacy for the use of telemedicine were placed under the legal and regulatory dimension. As for the quality check, two experts were assigned to evaluate the final list of articles. Both experts used a spreadsheet to compile their recommendations on whether the article 
was relevant to this study, and a consensus meeting was called to exchange their observations. The interrater reliability value was calculated using an item-by-item method, specifically by dividing the tally of agreements by the total number of agreements and disagreements, divided by 100 [16]. The average value for the interrater agreement was $86 \%$ (Fig. 1).

\section{Progress in telemedicine in SSA}

Our review of the literature (see Fig. 2-3 and Appendix) showed a number of attempts by individual governments, international partners and health organisations to develop the capacity of SSA countries to effectively execute telemedicine systems. In order to represent progress of telemedicine, we followed a similar trend by Dodoo, et al. [6] for the presentation of our results. Based on the African Union's regional economic groupings, the following key regions were emerged from the review of the literature: Community of Sahel-Saharan States (CSSS), Economic Community of West African States (ECOWAS), East African Community (EAC), South African Development Community (SADC) (https://au.int/en/organs/recs). The findings were categorised based on the existing regional segregation as follows:

\subsection{Community of Sahel-Saharan States (CSS)}

The early uptake of telemedicine in this region began in Ethiopia in 1980 under the HealthNet project. Between 1994 and 1997 Ethiopia established the Ethiopian Telecommunications Corporation (ETC) which recognized telemedicine as one of its services. However, these efforts were limited to planning and establishing the basis for piloting telemedicine in the region. Furthermore, between 2011 and 2012, through the Gezira Family Medicine Project in collaboration with the Faculty of Medicine, University of Gezira and the Ministry of Health, Sudan implemented a telemedicine program. Variants of telemedicine systems implemented include internal medicine, tele-paediatrics, dermatology, obstetrics and gynaecology, and e-learning via video conferencing.

Previous studies suggested that the implementation of telemedicine programs in this region has not seen much progress due to the lack of a framework for balancing multiple
Fig. 1 Study selection flowchart
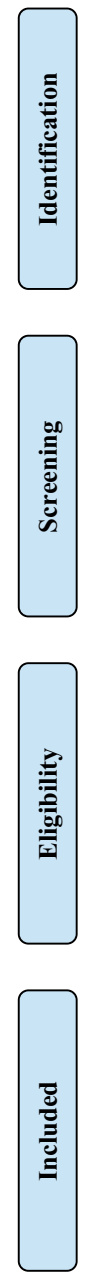
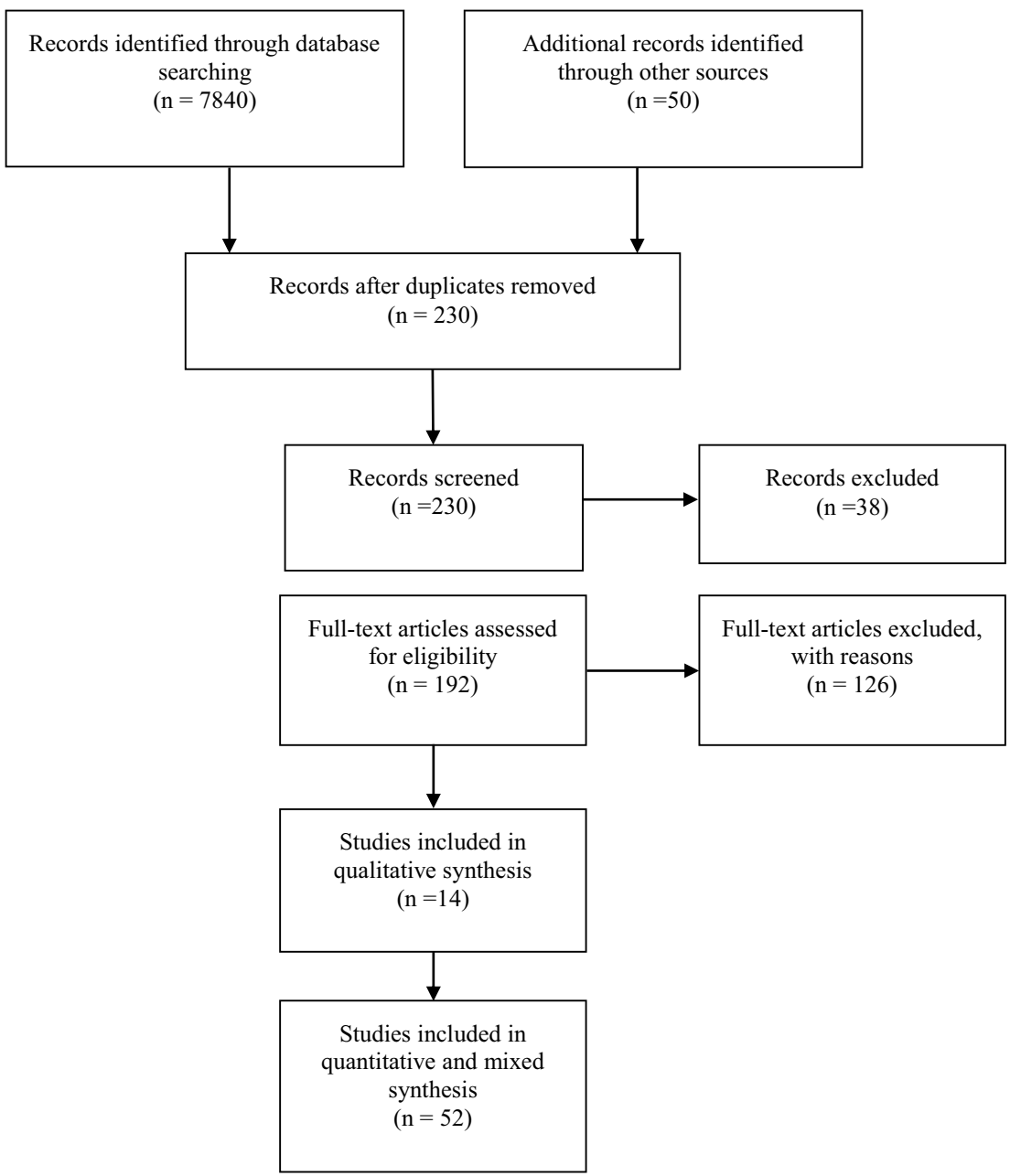
-Uganda and Kenya launched tele-education in corporation with The Child and Maternal Health Program (Uganda) and St. John's Memorial University, Canada

-Ethiopia piloted the Telemedicine project which consisted of tele-education, tele-dermatology, tele-pathology, tele-radiology, tele-ophthalmology, and tele-cardiology

1997

-Rwanda established the National Telemedicine project by providing Telemedicine centres and video conferencing facilities

-Kenya implemented tele-oncology to develop a comprehensive cancer care model

-South Africa launched its first telemedicine 2001 system

-Mali launched tele-consultations and distance education

-Mozambique and Senegal opened its first teleradiology using ISDN-based videoconferencing

-Senegal implemented in-service distance education for healthcare workers

-South Africa implemented tele-radiology and tele-dermatology

-Mozambique launched tele-radiology services in corporation with University hospital of Geneva by University hospital of Geneva

-Nigeria launched tele-education in support of society for telemedicine and e-Health

-Mauritius established its first telecardiography and tele-radiology

2005

-Mali launched the National tele-radiology

programme -Ethiopia launched Ethio-Indian

telemedicine program

-Angola set up tele-education via video-lecture with virtual internet patient simulators

2008

-Tanzania established the tele-paediatric program
-Ethiopia, Nigeria, Ghana, and Gambia

1980 established the HealthNet telemedicine project

-Uganda and Kenya established the Project SHARE in cooperation between St. John's (Canada) medical facility and Uganda

-Ethiopia government and foreign alliance implemented telemedicine

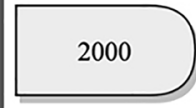

piloted its first telemedicine project in corporation with Malian Network of Information and Communication
-Ghana launched the Sene PDA national project to improve community healthcare delivery

-South Africa expanded its telemedicine

-Mauritania introduced Tele-radiology

Continuing medical education

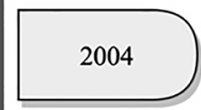

-Burkina Faso launched tele-dermatology, teleconsulting, tele-education

-South Africa established tele-dermatology by the University of Cape Town dermatology consultants

-Tanzania and Cameroon used telemedicine in maternal and child health through mobile clinic network

-Nigeria implemented tele-consultation, tele-ophthalmology, tele-dermatology, tele-ear, nose and throat
2007

-Mauritania introduced a pilot project on bronchoscopy training
-Angola launched tele-paediatric, tele-consultation, and tele-training between multiple hospitals

Fig. 2 Progress in telemedicine use in SSA countries [1980 - 2008] 
-Ghana in cooperation with international and local organisations improved its tele-consulting, tele-radiology, and tele-dermatology capabilities

-Uganda deployed videoconferencing between its hospitals and St Raphael Hospital in Millan, Italy

-Kenya introduced Mashavu telemedicine system for tele-consultation

-Botswana in collaboration with Indian universities, Botswana launched the Pan African Network tele-education

-Angola implemented telemedicine network in partnership with the Geneva University Hospitals (HUG) and the Portuguese Institute of Hygiene and Tropical Medicine

-South Africa introduced the general ethical guidelines for good practice in telemedicine

-Ethiopia introduced the national e-health policy initiative -Ghana expanded its tele-education, consultation, and surveillance services

-Ethiopia introduced maternal healthcare in Amhara region. It also upgraded its tele-radiology, ophthalmology, and tele-cardiology

-Botswana launched tele-ophthalmology in partnership with local and international agencies

-Burkina Faso used cloud-based tele-monitoring platform to monitor for red flags by midwives

-Botswana introduced a tele-oncology training program in cooperation with local and regional agencies

-Nigeria introduced tele-consultation in cooperation between Siloan Medical Centre and RubiconMD USA

-Kenya launched a telemedicine technology center for corona detection

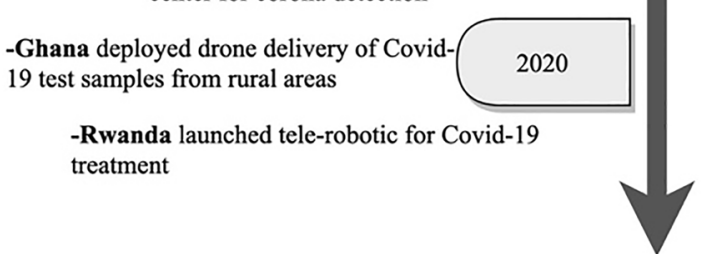

Fig. 3 Progress in telemedicine use in SSA countries [2009 - 2020]
-Ghana established a consultation network with the US named MedicareLine

2009 -Botswana launched Oral tele-medicine, teledermatology, tele-radiology with the support of ministry of health

-Botswana used Android-based myTouch 3G

smartphone to provide tele-education

-Mauritius set a plan to implement a national e-

health system

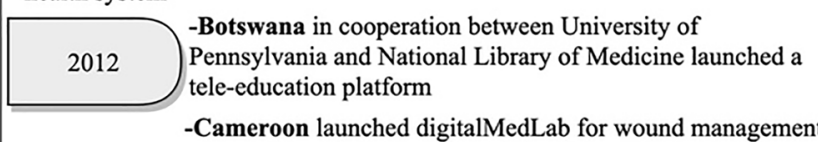

-Ethiopia used telemedicine software technologies from Switzerland

for Tele-dermatology, tele-radiology, and tele-pathology

-Botswana launched a Television White-Space pilot project for teleconsultation, tele-dermatology, cervical cancer and family medicine

-Tanzania launched a pilot project by World Aid Exchange (WaidX) and Radiation Department of National Center of Oncology

2015

-Ethiopia introduced e-maternal healthcare. It also extended its teleradiology, tele-dermatology, tele-ophthalmology and tele-pathology

-Mauritius launched Electronic Medical Record application. It also launched Robotic Assisted Surgery services and tele-diagnosis

-Gambia expanded the use of tele-radiology, tele-dermatology, and tele-pathology across the country

-Rwanda and Kenya launched tele-consulting and tele-diagnosis in cooperation with different local partners

-Uganda introduced consultation to health services in rural centres and referral hospitals

\section{9 \\ -Rwanda launched diabetes self-management \\ -Zimbabwe launched a new digital health application by the Zimbabwe Telemedicine Network (ZTN)}

-Ghana upgraded its consultation, tele-education, tele-ophthalmology services 
stakeholder interest. According to Kifle, et al. [17], most of the telemedicine projects faced various sustainability-related issues, especially after the completion of the project period. Also, a number of telemedicine initiatives were mostly funded from external support and lacked strategies for continuity and support from key stakeholders (Government, private sector, non-governmental organisations and the larger community) [18]. The failure to reach out to key stakeholders other than the healthcare sector may serve as a major challenge, especially in the area of system maintenance policy. Another key concern was the impact of telemedicine on existing workstructure. We identified that most healthcare professionals in the region face enormous workload. This led healthcare professional to view telemedicine system as an additional task that would result in increased workload and time consuming $[19,20]$. These factors serve as a vital challenge and can potentially constrain the progress of telemedicine projects.

\subsection{Economic community of West African States (ECOWAS)}

Most of the early telemedicine projects started in countries such as Nigeria, Ghana, and Gambia in 1980 under the HealthNet project. Between 2000-2001 Mali was the first to successfully pilot a telemedicine program in cooperation with the Malian network of information and communication. The piloted project was mainly aiming at providing internet-based technologies for distance learning and teleconsultations. Other countries, such as Senegal, followed suit with the same measures to implement telemedicine using videoconferencing methods with a focus on patient care. Between 2003 and 2007, more improvements in the use of telemedicine systems have been reported across Ghana, Nigeria, and neighbouring countries. This includes using telemedicine for cancer care and education. In addition, the use of teleradiology, telepathology, and tele-oncology was initially introduced in these countries in an attempt to increase the reach of these services to rural areas. For example, Ghana in 2009 established a consultation network with Medicare line (US) to facilitate the communication between physicians and surgeons using free calls and SMS messages. In 2017, the governments of some countries like Burkina Faso, and Nigeria launched initiatives to integrate cloud computing for building their telemedicine infrastructure. This includes providing surveillance of certain patients and spread of disease, as well as advancing capacity of teleconsultation and monitoring services in these countries. In 2019, Ghana focused on upgrading the current telemedicine services to reach their full potential in smaller rural communities. Recently, the utilization of telemedicine services in this region has increased dramatically due to various challenges associated with COVID-19 and the need for continued healthcare provision. Ghana has also shown progress in using telemedicine by deploying drone delivery of COVID-19 test samples from rural areas.

\subsection{East African community (EAC)}

Kenya and Uganda introduced a telemedicine project in cooperation with several international organizations from 1980 till 1982 to plan for technology implementation. Other countries, such as Rwanda, Kenya, followed suit with the same measures to ensure effective use of telemedicine using videoconferencing methods with a focus on patient care. Between 2003 and 2007, more improvements in the use of telemedicine systems have been reported across Tanzania, and neighbouring countries for cancer care and education. In addition, there was expansion of telemedicine services to include teleradiology, telepathology, and tele-oncology in order to increase the reach of these services to underserved communities. Between 2007 and 2008, Tanzania was successful in introducing tele-paediatrics to increase their capacity for delivering specialist paediatric and child healthcare services. Another major development was in the involvement of international corporations, as a key source of technology transfer in the region.

In addition, the increasing popularity of e-health and m-health technologies, especially between 2012-2016, has led to a rapid growth of telemedicine services in the region. In 2019, countries like Uganda, Rwanda, Zimbabwe, have focused on upgrading the current telemedicine services to reach their full potential in smaller rural communities. For example, Rwanda launched a new diabetes self-management centre to help provide care and monitor patients in rural areas. This includes the launch of telemedicine centre to assist hospitals in detecting COVID-19 cases in Kenya. Rwanda introduced tele-robotics to treat COVID-19 cases. Uganda witnessed an increased use of teleconsultation to ensure continuity of healthcare for patients, established call centres and online health to provide triage and referral services to the general public. In addition, mobile SMS services were employed widely to spread awareness about COVID-19 infection and prevention measures.

\subsection{Southern African development community (SADC)}

A successful attempt to use telemedicine services (mainly internet-based technologies) was achieved by South Africa and Mozambique for distance learning and teleconsultations between 2000-2001. A further development in the utilization of telemedicine was noted between 2002 and 2003 through the expansion of care services to rural and urban areas of South Africa. Between 2003 and 2007, more improvements in the use of telemedicine systems have been reported across the country. This includes using telemedicine for cancer care and education. In addition, the use of teleradiology, telepathology, and tele-oncology was introduced in SADC countries to expand the range of their telemedicine services. 
Between 2007 and 2008, Angola was successful in introducing tele-paediatrics to expand specialist paediatric and child healthcare services. These efforts at health technology transfer in the region were successful in partnership with international corporations. For example, the current 3G network Smartphone equipped with data in Botswana enhances faster health information transmission, quicker medical response and improved patient outcomes. This has advanced the growth of telemedicine program in the region by offering conversational tele-education and teleconsultation services. Also, Mauritius and Botswana have implemented a nationwide telehealth project in an attempt to promote a wider access for patient care while advancing medical education for physicians by providing comprehensive active clinical programs, virtual educational programs, and electronic libraries. In 2017, the governments of Botswana launched initiatives to integrate cloud computing for building their telemedicine infrastructure. This includes providing surveillance of certain patients and spread of disease, as well as advancing the capacity of teleconsultation and monitoring services in these countries. The negative impact of COVID19 and the potential spread of the virus through face-to-face hospital attendance influenced the Health Professions Council of South Africa to revise restrictions on the current telemedicine practices. This represents a breakthrough in terms of progress and acceptance of telemedicine implementation.

\section{Implications for healthcare practitioners and providers}

This study reported the progress in relation to the development of telemedicine programs in specific regions in SSA. Our review of the literature (see Appendix) suggests that a reasonable progress has been made to effectively use telemedicine in SSA, in particular during the COVID-19 period. Yet, many knowledge gaps still remain in terms of the extent of usage and suitability. This study shed the light on progress made by individual countries/regions in SSA to implement telemedicine.

We found variations in terms of extent of telemedicine applications across SSA countries. Most of the telemedicine systems were implemented on a pilot project basis. For example, aside from the initial telemedicine start-up projects, in the community of Sahel Saharan States (particularly Ethiopia), the existing literature pointed to less progress in implementing and expanding telemedicine services. This finding provides policy directions for stakeholders to invest in digital health innovations to help address challenges related to accessing healthcare provision in the region.

In addition, our findings showed how a range of telemedicine services can be implemented in the regions of ECOWAS, EAC and SADC, thus signifying some level of progress in these regions. The study's findings may potentially pave the way for scaling up telemedicine services. For example, the results show that tele-education can be used extensively for medical education in most SSA countries. This may potentially offer an effective way for strategic regional collaboration that is useful for training medical personnel. It is particularly significant for facilitating exchange programmes among medical students in SSA. In addition, it will facilitate some level of parity in the development of human resource for telemedicine practices. The effective use of tele-education can address the challenges associated with the lack of telemedicine expertise among clinicians, ethical and privacy concerns, which were identified as barriers to the successful implementation of telemedicine systems [6]. Aside from these, tele-education has implication for promoting mobility of medical personnel across regions and countries in SSA.

Another issue worthy of attention was related to the use of the store-and-forward method in most of the telemedicine services. By this method, patients' medical information is sent for expert review via email, messages or the eHealth system. However, the store-and-forward method has been reported to be deficient in generating user satisfaction of telemedicine due to the lack of a real-time experience. We, therefore, recommend policy makers to include video-conferencing and other advanced methods to enhance the quality of services and continued usage of the system. This can potentially improve users' perception about digital health technology and services, thus leading to sustainability and value creation. We recommend for further research to document initiatives on digital health technology usage and empirically assess their impact on healthcare practice in SSA.

\section{Conclusion}

This study traced the implementation of telemedicine programs in SSA and grouped progress according to the regional categorisation. Extensive use of tele-education services in the training of medical students was reported across SSA. This can promote regional collaboration across SSA by increasing standardisation of telemedicine practices. The findings from the literature review suggests that the implementation of telemedicine systems in the Sahel-Saharan States has not seen much progress in terms of expansion of services following the completion of the initial projects. Further, our review suggests that reasonable progress has been made in the ECOWAS and EAC regions in terms of implementation, expansion and sustainability of telemedicine systems and services, especially during the COVID-19 period. The SADC has been successful in implementing a broad range of telemedicine systems and services, which is backed by strong national legislations to support its sustainability. Based on the above, the unbalanced implementation of telemedicine systems calls for urgent stakeholder attention to improve the current healthcare provision for increased user acceptance and satisfaction. 


\section{Appendix}

Table 1

\begin{tabular}{|c|c|c|c|c|}
\hline References & $\begin{array}{l}\text { Regions/ } \\
\text { Countries }\end{array}$ & Service collaborators & Telemedicine service & Telemedicine systems \\
\hline & CSSS & & & \\
\hline $\begin{array}{l}\text { Mbarika [21]; Kifle et al. [22]; } \\
\text { Lemma et al. [23]; Kifle et al. } \\
\text { [17]; Shiferaw and Zolfo [24]; } \\
\text { Hailemariam et al. [18]; Abera } \\
\text { et al. [25]; Medhanyie et al. [19]; } \\
\text { Xue et al. [26];Shiferaw et al. } \\
\text { [27]; Weldegebrial and Berhie } \\
\text { [28] }\end{array}$ & Ethiopia & $\begin{array}{l}\text { HealthNet telemedicine project, } \\
\text { Addis Ababa University (AAU), } \\
\text { British Council Telecenter, the } \\
\text { International Telecommunication } \\
\text { Union, WHO, ORBIS Ministry of } \\
\text { Health, ETC, UNECA, UNESCO, } \\
\text { United Naions Economic } \\
\text { Commission for Africa, infoDev }\end{array}$ & $\begin{array}{l}\text { Tele education, tele } \\
\text { dermatology, } \\
\text { telepathology, } \\
\text { teleradiology, tele } \\
\text { ophthalmology, } \\
\text { telecardiology, } \\
\text { e-maternal } \\
\text { health care; }\end{array}$ & $\begin{array}{l}\text { Dial up internet } \\
\text { connection, LAN; } \\
\text { Personal computer, } \\
\text { digital cameras, } \\
\text { telemedicine } \\
\text { software; Store- } \\
\text { and-forward; WDS } \\
\text { technologies from } \\
\text { Switzerland; remote } \\
\text { patient monitoring }\end{array}$ \\
\hline \multirow[t]{2}{*}{$\begin{array}{l}\text { Colt, et al. [29]; Bagayokoa, et al. } \\
\text { [30] }\end{array}$} & Mauritania & $\begin{array}{l}\text { Pilot project with the World } \\
\text { Bronschology Foundation and } \\
\text { Nauadhibou Regional Hospital }\end{array}$ & $\begin{array}{l}\text { Tele education, } \\
\text { Teleradiology } \\
\text { Continuing medical } \\
\text { education, }\end{array}$ & Web-based instruction \\
\hline & ECOWAS & & & \\
\hline $\begin{array}{l}\text { Mbarika [21]; Adebola and } \\
\text { Lawson [31]; Mars [32]; } \\
\text { Godstime et al. [33]; } \\
\text { Olayiwola, et al. [34] }\end{array}$ & Nigeria & $\begin{array}{l}\text { HealthNet telemedicine project; } \\
\text { Society for Telemedicine and } \\
\text { e-Health in Nigeria (SFTeHIN), } \\
\text { WHO Telemedicine centres, } \\
\text { Norway Telemedicine centre, } \\
\text { National Information Technology } \\
\text { Development Agency, Pan African } \\
\text { e-Network clinical telemedicine } \\
\text { project, Ibadan Super Specialty } \\
\text { hospital, California Hospital, USA } \\
\text { Siloan Medical Centre in } \\
\text { partnership with RubiconMD USA }\end{array}$ & $\begin{array}{l}\text { Medical alerts, Tele } \\
\text { education, } \\
\text { Teleconsultation, } \\
\text { teleophthalmology, tele } \\
\text { dermatology, } \\
\text { tele-ear, nose and } \\
\text { throat, teleconsultation }\end{array}$ & $\begin{array}{l}\text { Video conferencing, } \\
\text { Image \& illumination } \\
\text { system, cameras, } \\
\text { electronic stethoscope }\end{array}$ \\
\hline $\begin{array}{l}\text { Mbarika [21]; Kennedy et al. [35]; } \\
\text { Luk et al. [36]; Mars [32]; Yusif } \\
\text { and Jeffrey [37]; } \\
\text { Nyame-Asiamah [38]; Tchao } \\
\text { et al. [39](2019); } \\
\text { https://www.novartisfoundation. } \\
\text { org/our-work/reimagining- } \\
\text { healthcare-through-digital- } \\
\text { technology/ghana-telemedicine; } \\
\text { https://allafrica.com/stories/ } \\
\text { 202004300181.html; https:// } \\
\text { www.voanews.com/COVID-19- } \\
\text { pandemic/COVID-19-drives- } \\
\text { health-care-tech-innovation- } \\
\text { ghana }\end{array}$ & Ghana & $\begin{array}{l}\text { HealthNet telemdicine project, } \\
\text { London School of Hygiene and } \\
\text { Tropical Medicine, Geneva, Korle } \\
\text { Bu hospital (Ghana) and } \\
\text { Moorfields eye hospital London, } \\
\text { Ghana Consultation Network } \\
\text { and US, MedicareLine (Ghana), } \\
\text { Pan African e-Network clinical } \\
\text { telemedicine project, Novartis } \\
\text { Foundation, Millenium Promise } \\
\text { Alliance, Earth Institute, Columbia } \\
\text { University, St. Martin's Hospital, } \\
\text { MedGate, Ericsson and Airtel, } \\
\text { Sandford US based (2012), Family } \\
\text { health hospital in collaboration } \\
\text { with Family Health Group Apollo } \\
\text { Hospital (India), eNetwork, } \\
\text { Zipline drone-delivery, health } \\
\text { care tech company Redbird (rapid } \\
\text { testing), Talamus Health Ghana } \\
\text { company }\end{array}$ & $\begin{array}{l}\text { Research, surveillance, } \\
\text { Teleophthalmology, } \\
\text { Continuous } \\
\text { education, } \\
\text { e-consultation, } \\
\text { Telemedicine } \\
\text { education, } \\
\text { teleradiology, tele } \\
\text { dermatology, COVID- } \\
19 \text { testing, COVID-19 } \\
\text { healthcare (diagnose, } \\
\text { monitor infections) }\end{array}$ & $\begin{array}{l}\text { Web-based } \\
\text { telemedicine } \\
\text { application, } \\
\text { asynchronously } \\
\text { synchronized, Video, } \\
\text { store-and-forward } \\
\text { conferencing Mobile } \\
\text { application, video } \\
\text { appointment }\end{array}$ \\
\hline
\end{tabular}




\begin{tabular}{lll}
\hline References & $\begin{array}{l}\text { Regions/ } \\
\text { Countries }\end{array}$ & Service collaborators \\
\hline $\begin{array}{l}\text { Caumes et al. [40]; Jacq et al. [41]; } \\
\text { Diallo et al. [42]; Arnaert et al. }\end{array}$ & Burkina Faso & $\begin{array}{l}\text { Physicians in Burkina Faso and } \\
\text { France (Clermont-Ferrand), }\end{array}$ \\
[43] & & $\begin{array}{l}\text { Developed by Davycas } \\
\text { International and Financed by the }\end{array}$ \\
& & $\begin{array}{l}\text { MenAfriNet Consortium, BELT } \\
\text { framework, funded through Grand }\end{array}$ \\
& & Challenges Canada
\end{tabular}

Mbarika [21]; Kennedy, et al. [35]; Gambia http://origin.who.int/goe/ publications/atlas/2015/gmb.pdf; http://www.aiu.edu.gm/ aiu_telemedicine.html

Mbarika and Okoli [44];

Geissbuhler et al. [45]

Geissbuhler et al. [45]; Mars [32]; Bagayokoa et al. [30]; Sangare et al. (2015)

Mali

Senegal

HealthNet telemedicine project, Royal Victoria Teaching Hospital (Gambia) with Moorfields eye hospital London, AIUWA

(American International University West Africa) Telemedicine centre, partners African Union, Government of The Gambia and Pan African eNetwork project (India)

\section{SONATEL}

(telecommunication operator in Senegal), Lille Regional University hospital and the European Institute of Telemedicine in Toulouse partnership

National Telemedicine Project in Mali partnership with Mali University Medical School and Geneva University Hospital. First telemedicine pilot project by Malian Network of Information and Communication, funded by State of Geneva, RAFT (Network in French speaking Africa for Telemedicine)

CAC

Katzenstein et al. [46]; Kingue et al. [47];

https://www.movementdisorders. org/MDS/Regional-Sections/

Sub-Saharan-Africa/

Telemedicine-in-Douala-

Cameroon-.htm; https://www.

idgconnect.com/idgconnect/ interviews/1028321/cameroontelemedicine-approach-woundmanagement
Telemedicine service Telemedicine systems
Tele dermatology, teleconsulting, tele education, Diabetic retinopathy,

Tele-surveillance, Antenatal healthcare, Nationwide cloud-based meningitis surveillance and specimen tracking system (STELAB) for real-time data reporting
Teleophthalmology, Teleradiology, tele dermatology, telepathology, Tele education point-and-shoot digital camera equipped with a Carl Zeiss Vario Sonnar lens and a flash, Grid technologies Healthgrid (stores data of medical interest for easy access in healthcare), Barcodes for tracking, onlineoffline application, cloud-based telemonitoring platform (used to monitor for red flags by midwives)

Web-based telemedicine application
In-service distance education for healthcare workers, Telecardiology and teleneurology, teleechography

Teleconsultations and distance education, Teleradiology

Continuing medical education
Teleconferencing, storeand-forward method of information transmission, ISDNbased Visio conference

IKON hardware and software X-ray and mammogram images, IKON platform
Tele education, Maternal health; Wound management; Telecardiology
WoundDesk Mobile app

Telemedcam mobile app, real-time and asynchronous interaction 


\begin{tabular}{|c|c|c|c|c|}
\hline References & $\begin{array}{l}\text { Regions/ } \\
\text { Countries }\end{array}$ & Service collaborators & Telemedicine service & Telemedicine systems \\
\hline & EAC & & & $\begin{array}{l}\text { X-ray and } \\
\text { mammogram images, } \\
\text { IKON platform }\end{array}$ \\
\hline $\begin{array}{l}\text { Mbarika and Okoli [44]; Qin et al. } \\
\text { [48]; Ferrari et al. [49]; } \\
\text { https://www.ncbi.nlm.nih.gov/ } \\
\text { pmc/articles/PMC1492060/pdf/ } \\
\text { cmaj00136-0088.pdf; https:// } \\
\text { www.scidev.net/sub- } \\
\text { saharan-africa/medicine/news/ } \\
\text { kenya-launches-telemedicine- } \\
\text { initiative-poor.html?; https:// } \\
\text { www.axisimagingnews.com/ } \\
\text { news/kenya-opens-first- } \\
\text { telemedicine-center-for-COVID- } \\
\text { 19-detection }\end{array}$ & Kenya & $\begin{array}{l}\text { International Satellite Organisation } \\
\text { and Project SHARE. St. John's } \\
\text { (Canada) medical facility and } \\
\text { Nairobi medical faculties, } \\
\text { Canadian International } \\
\text { Development Agency (CIDA), } \\
\text { AMPATH-Oncology with North } \\
\text { America, Mashavu Telemedicine } \\
\text { system, National telemedicine } \\
\text { project, Kenyatta National } \\
\text { Hospital, Kenya Ministry of } \\
\text { Health and Merck Group } \\
\text { Germany, Telemedicine } \\
\text { technology center for corona } \\
\text { detection }\end{array}$ & $\begin{array}{l}\text { Tele-ECG, Enhanced } \\
\text { medical education, } \\
\text { Tele education, Tele } \\
\text { oncology, } \\
\text { Teleconsultation, } \\
\text { telediagnosis, tele } \\
\text { detection }\end{array}$ & $\begin{array}{l}\text { Video conferencing, } \\
\text { VIA (Visual } \\
\text { inspection with acetic } \\
\text { acid, store-and- } \\
\text { forward system, }\end{array}$ \\
\hline $\begin{array}{l}\text { Mbarika and Okoli [44]; } \\
\text { https://www.ncbi.nlm.nih.gov/ } \\
\text { pmc/articles/PMC1492060/pdf/ } \\
\text { cmaj00136-0088.pdf }\end{array}$ & Uganda & $\begin{array}{l}\text { International Satellite Organisation } \\
\text { and Project SHARE, St. John's } \\
\text { (Canada) medical facility and } \\
\text { Uganda, The Child and Maternal } \\
\text { Health Program (Uganda), } \\
\text { Canadian International } \\
\text { Development Agency (CIDA), } \\
\text { Pan African e-Network clinical } \\
\text { telemedicine continuing } \\
\text { telemedicine project and Makerere } \\
\text { University, } \\
\text { Ugandan hospitals and St Raphael } \\
\text { Hospital in Millan, Italy } \\
\text { Hospitals in Kampala. Launch of } \\
\text { Coolscope at Mulago Hospital } \\
\text { Ugandan health services in rural } \\
\text { centres and referral Hospitals }\end{array}$ & $\begin{array}{l}\text { Tele-ECG, Teleeducation } \\
\text { Teleconsulting, } \\
\text { Telepathology, }\end{array}$ & \\
\hline $\begin{array}{l}\text { https://allafrica.com/stories/ } \\
\text { 201905130465.html }\end{array}$ & Zimbabwe & Zimbabwe Telemedicine Network & & $\begin{array}{l}\text { Videoconferencing, } \\
\text { store-and-forward }\end{array}$ \\
\hline $\begin{array}{l}\text { Kennedy et al. [35]; Katzenstein } \\
\text { et al. [46]; Krüger and Niemi } \\
\text { [50]; Balogun et al. [51]; }\end{array}$ & Tanzania & $\begin{array}{l}\text { CCBRT Disability hospital } \\
\text { (Tanzania) with Moorfields eye } \\
\text { hospital London, } \\
\text { Mission Mikocheni Hospital } \\
\text { (Tanzania), HealthSpan } \\
\text { International foundation (USA), } \\
\text { Tanzanian Telemedicine Network } \\
\text { with open-source software iPath } \\
\text { Pilot project by World Aid Exchange } \\
\text { (WaidX) and Radiation } \\
\text { Department of National Center of } \\
\text { Oncology, Yerevan, Armenia }\end{array}$ & $\begin{array}{l}\text { Teleophtalmology, } \\
\text { Maternal and child } \\
\text { health, Telepaediatric, } \\
\text { Teleoncology, }\end{array}$ & $\begin{array}{l}\text { Web-based } \\
\text { telemedicine } \\
\text { application } \\
\text { mobile clinic network } \\
\text { Store-and-forward via } \\
\text { Videoconferencing }\end{array}$ \\
\hline
\end{tabular}




\begin{tabular}{l}
\hline References \\
\hline Nchise et al. [52]; Murererehe \\
et al. [53]; Kabeza et al. [54]; \\
https://spidercenter.org/files/2017/ \\
07/Report-Telehealth-Rwanda- \\
100710-Web.pdf; https:// \\
allafrica.com/stories/ \\
202005140352.html
\end{tabular}

Bholah and Beharee [55];

Beebeejaun and Chittoo [56];

Ratna et al. [57];

https://mauritiusclinics.com/en/ our-services/our-medicalservices/medical-services/ telemedicine

Mbarika and Okoli [44]; Mbarika [21]; Geissbuhler et al. [45]; Colt et al. [29],

Gulube and Wynchank [58]; Fortuin and Molefi [12]; Mars [59]; Kennedy et al. [35]; Mars [32]; Colven et al. [60]; Webster [7];

http://www.kznhealth.gov.za/ telemedicine1.pdf; http://www. kznhealth.gov.za/telemedicine1. pdf; https://www.hoganlovells. com/en/publications/theregulation-of-telemedicine-insouth-africa

\begin{tabular}{llcl}
$\begin{array}{l}\text { Regions/ } \\
\text { Countries }\end{array}$ & Service collaborators & Telemedicine service & Telemedicine systems \\
& & & \\
\hline Rwanda & National Telemedicine project and & Telemedical training, & video conferencing \\
& Rwanda Ministry of Health, & Teleconsulting and & facilities, PAN- \\
& Ministry of IT Authority and & telediagnosis, & African e-network \\
& Partners from Belgian & Tele dentistry, Diabetes & satellite, LMS, \\
& Technology operation, Pan- & self-management, & Humanoid robots with \\
& African E-network, SMART & Tele-robotic for & video conferencing \\
& Rwanda master plan, eC3-electro & COVID-19 treatment & capacity to connect to \\
& cervical cancer control program, & & doctor, 'Kir'App' via \\
& Kigali Hospital, Rwanda's vision & & smartphone
\end{tabular}

2020 agenda, Open Medical

Record System (OpenMRS),

TRACnet and TRACPlus and

HMIS health intervention projects,

First Rwanda diabetes self-

management application

(Kir'App), CRUZR robots, manufactured by Kigali-based

Belgian robotic tech firm

(Zorabots), Rwanda Biomedical

Centre, Rwanda Information

Society Authority and Rwanda

Utilities Regulatory Authority

Mauritius The SAFE project, Clinique du

Nord with Manipal Hospital in

India; e-Health start-up project in

collaboration with the Mauritius

Research Council and State

Informatics Limited, Appollo

Bramwell Hospital

Mozambique University hospital of Geneva,

The Telecommunications

Development Bureau of the

International Telecommunications

Union, Central hospitals of Beira and Maputo, SATELLIFE,

A demonstration project between (FISSA) Dakar and Mozambique,

Pilot project on bronschoscopy training with grant from the World Bronschology Foundation and Maputo Central Hospital

SADC

South Africa National Telemedicine system (launched pilot project phase I, Mindset Health channel with National Department of Health, Mindset and Sentech, the Medical Research Council of South Africa, PHASE II - effective telemedicine connection, PHASE III additional and affordable telemedicine healthcare (Transfer from pilot stage to clinical and operational stage), Groote Schuur Hospital (Cape Town,SA) in partnership with Moorfields eye hospital London
Tele cardiography and teleradiology;

Teleconsultation, Robotic Assisted Surgery services, telediagnosis

Teleradiology

Teleeducation

Teleradiology

Tele education

Teleradiology, tele-ultrasound (antenatal services), telepathology and teleophthalmology, tele dermatology, programme in medical education
Electronic Medical Record application, "Da Vinci System" features magnified 3D high-definition vision system

Digital microwave transmission, terrestrial satellite telecommunication systems, WDS Technology, standard low-cost teleradiology equipment, ISDN-based Visio conferencing, Web-based instruction

ISDN at $256 \mathrm{kbit} / \mathrm{s}$, Store-and-forward, satellite, computer, television screen, Web-based telemedicine application, Video conferencing, CT scanners, store-andforward technology 


\begin{tabular}{|c|c|c|c|c|}
\hline References & $\begin{array}{l}\text { Regions/ } \\
\text { Countries }\end{array}$ & Service collaborators & Telemedicine service & Telemedicine systems \\
\hline $\begin{array}{l}\text { Littman-Quinn et al. [61]; } \\
\text { Armstrong et al. [62]; Chang } \\
\text { et al. [63]; Munyoka [64]; } \\
\text { Chavez et al. [65]; Chandar et al. } \\
\text { [66]; } \\
\text { https://www.odess.io/files/ } \\
\text { documents/enquetes/ } \\
\text { CR_ODESS2017-Peek_ } \\
\text { English.pdf }\end{array}$ & Botswana & $\begin{array}{l}\text { Botswana-UPenn Partnership, The } \\
\text { Ministry of Health of Botswana, } \\
\text { Clinton Health Access } \\
\text { Initiative, University of Botswana, } \\
\text { the National Library of Medicine, } \\
\text { Positive Innovation for the Next } \\
\text { Generation (PING), Hewlett- } \\
\text { Parkard, Orange Foundation and } \\
\text { Mascom Wireess, University of } \\
\text { Botswana School of Medicine } \\
\text { (SOM) and Resident Physicians } \\
\text { (remote areas), Pan African } \\
\text { Network Tele-education projecct } \\
\text { to support distance education, } \\
\text { Television White-Space pilot } \\
\text { project (Project Kgolagano), } \\
\text { Innovation Hub Microsoft, Vista } \\
\text { Life Sciences, Global Broadband } \\
\text { Solution, Standard Chartered } \\
\text { Bank, Rugers-Cancer Institute of } \\
\text { New Jersey (R-CINJ) fellowship } \\
\text { program, partnerships with } \\
\text { Rutgers Global Health and } \\
\text { University of Botswana }\end{array}$ & $\begin{array}{l}\text { Oral telemedicine, } \\
\text { Teledermatology, } \\
\text { teleradiology, } \\
\text { Teleducation, } \\
\text { Teleconsultation, } \\
\text { cervical and family } \\
\text { medicine, } \\
\text { Teleophthamology, } \\
\text { Teleoncology training }\end{array}$ & $\begin{array}{l}\text { mobile technology, } \\
\text { Android-based } \\
\text { myTouch 3G } \\
\text { smartphone equipped } \\
\text { with data-enabled } \\
\text { subscriber identity } \\
\text { module and built-in } \\
\text { camera, e-mails/ } \\
\text { Web access, } \\
\text { Tele-education } \\
\text { Learning } \\
\text { Management System } \\
\text { (IP-based and VSAT } \\
\text { networks), TV White } \\
\text { Space technology, } \\
\text { Potable Eye } \\
\text { Examination Kit } \\
\text { (Peek vision } \\
\text { technology) }\end{array}$ \\
\hline $\begin{array}{l}\text { Dinis et al. [67]; Bediang et al. } \\
\text { [68]; Zennaro et al. [69]; Correia } \\
\text { et al. [70] }\end{array}$ & Angola & $\begin{array}{l}\text { PEDITEL project, Europe-Africa } \\
\text { Telemedicine network, } \\
\text { collaboration between hospitals } \\
\text { in Angola and Portugal, Angola } \\
\text { Telecom, Multitel, Unitel } \\
\text { RAFT project } \\
\text { Hospital Divina Providencia and } \\
\text { IRCCS Burlo project } \\
\text { Angolan National Telemedicine } \\
\text { Network in partnership with the } \\
\text { Geneva University Hospital and } \\
\text { Portuguese Institute of hygience } \\
\text { and Tropical Medicine, RAFT } \\
\text { network }\end{array}$ & $\begin{array}{l}\text { Telepediatric, } \\
\text { teleconsultation, } \\
\text { tele-training } \\
\text { Teleducation } \\
\text { Teleradiology }\end{array}$ & $\begin{array}{l}\text { videoconferencing, } \\
\text { real-time } \\
\text { teleconsulting, ISDN } \\
\text { lines } \\
\text { Video-lecture with } \\
\text { Dudal, virtual internet } \\
\text { patient simulators } \\
\text { (VIPS) } \\
\text { X-ray photosensitive } \\
\text { screens }\end{array}$ \\
\hline
\end{tabular}

Funding NA.

\section{Declarations}

Research involving human participants and/or animals NA.

Informed consent NA.

Conflicts of interest The authors have no conflicts of interest.

Open Access This article is licensed under a Creative Commons Attribution 4.0 International License, which permits use, sharing, adaptation, distribution and reproduction in any medium or format, as long as you give appropriate credit to the original author(s) and the source, provide a link to the Creative Commons licence, and indicate if changes were made. The images or other third party material in this article are included in the article's Creative Commons licence, unless indicated otherwise in a credit line to the material. If material is not included in the article's Creative Commons licence and your intended use is not permitted by statutory regulation or exceeds the permitted use, you will need to obtain permission directly from the copyright holder. To view a copy of this licence, visit http://creativecommons.org/licenses/by/4.0/.

\section{References}

1. Wootton R, Bonnardot L. Telemedicine in low-resource settings. Front Public Health. 2015;3:3.

2. Gutierrez M, Moreno R, Rebelo M. "Information and communication technologies and global health challenges," in Global Health Informatics. Elsevier, 2017;50-93.

3. Smith AC, et al. Telehealth for global emergencies: Implications for coronavirus disease 2019 (COVID-19). J Telemed Telecare. 2020;26(5):309-13.

4. Ohannessian R. Telemedicine: potential applications in epidemic situations. European Research in Telemedicine/La Recherche Européenne en Télémédecine. 2015;4(3):95-8.

5. Behar JA, et al. "Remote health monitoring in the time of COVID19." https://arxiv.org/abs/2005.085372020. 
6. Dodoo JE, Al-Samarraie H, Alzahrani AI. "Telemedicine Use in Sub-Saharan Africa: Barriers and Policy Recommendations for Covid-19 and Beyond." Intern J Med Informat. 2021;151:104467.

7. Webster P. Virtual health care in the era of COVID-19. The Lancet. 2020;395(10231):1180-1.

8. Holst C, Sukums F, Radovanovic D, Ngowi B, Noll J, Winkler AS. Sub-Saharan Africa-the new breeding ground for global digital health. Lancet Digit Health. 2020;2(4):e160-2.

9. Adepoju P. Africa turns to telemedicine to close mental health gap. Lancet Digit Health. 2020;2(11):e571-2.

10. Edoh TO, Kora AD, Pawar P, Coulibaly GC, Alahassa BR. Predicting telemedicine system user satisfaction in sub-Saharan Africa. ICT Express. 2016;2(4):163-7.

11. Adebayo PB, Oluwole OJ, Taiwo FT. COVID-19 and Teleneurology in Sub-Saharan Africa: Leveraging the Current Exigency. Front Public Health. 2020;8:1-7.

12. Fortuin J, M. Molefi M. "Telemedicine in South Africa." Adv Intern Telemed eHealth, 2006;1.

13. Liberati A, et al. "The PRISMA statement for reporting systematic reviews and meta-analyses of studies that evaluate health care interventions: explanation and elaboration." PLoS Med. 2009;6(7):e1000100.

14. Dodoo JE, Al-Samarraie H. Factors leading to unsafe behavior in the twenty first century workplace: a review. Manag Rev Q. 2019;69(4):391-414.

15. Fisch C, Block J. Six tips for your (systematic) literature review in business and management research. Manag Rev Q. 2018;68:103-6.

16. Cooper JO, Heron TE, Heward WL. Applied behavior analysis, 2nd ed. Upper Saddle River, NJ: Pearson/Merrill/Prentice-Hall, 2007.

17. Kifle M, Mbarika VW, Bradley RV. Global diffusion of the internet $\mathrm{x}$ : the diffusion of telemedicine in ethiopia: potential benefits, present challenges, and potential factors. Commun Assoc Inf Syst. 2006;18(1):30.

18. Hailemariam G, Garfield MJ, Kebede AA, Musa PF. "Stakeholders Analysis of Ethiopian Telemedicine Projects, the case of Black Lion Hospital, Addis Ababa, Ethiopia." in 19th AmConf Inform Syst. AMCIS, 2013;3066-3075.

19. Medhanyie AA, et al. Health workers' experiences, barriers, preferences and motivating factors in using mHealth forms in Ethiopia. Hum Resour Health. 2015;13(1):2.

20. Biruk K, Abetu E. "Knowledge and attitude of health professionals toward telemedicine in resource-limited settings: a cross-sectional study in North West Ethiopia." J Healthcare Eng. 2018, 2018.

21. Mbarika VW. Is telemedicine the panacea for Sub-Saharan Africa's medical nightmare? Commun ACM. 2004;47(7):21-4.

22. Kifle M, Solomon A, Okoli C, Mbarika V. "Critical success factors for telemedicine in Ethiopia," in Information Resources Management Association (IRMA 2004). New Orleans, 2004;1-14.

23. Lemma F, Atnafu S, Kassegne SK. Survey of Current Efforts and Potentials in Application of Telemedicine in Ethiopia. Addis Ababa University. 2004;17:2006.

24. Shiferaw F, Zolfo M. The role of information communication technology (ICT) towards universal health coverage: the first steps of a telemedicine project in Ethiopia. Global Health Aaction. 2012;5(1): 15638 .

25. Abera AA, Mengesha GH, Musa PF. Assessment of Ethiopian health facilities readiness for implementation of telemedicine. Commun Assoc Inf Syst. 2014;34(1):67.

26. Xue Y, Liang H, Mbarika V, Hauser R, Schwager P, Getahun MK. Investigating the resistance to telemedicine in Ethiopia. Int $\mathrm{J}$ Med Informatics. 2015;84(8):537-47.

27. Shiferaw S, Spigt M, Tekie M, Abdullah M, Fantahun M, Dinant G-J. "The effects of a locally developed mHealth intervention on delivery and postnatal care utilization; a prospective controlled evaluation among health Centres in Ethiopia," PloS One, 2016; 11(7).
28. Weldegebrial TT, Berhie G. "Telehealth in Ethiopia-The Barriers Vs. The Success Factors." Marshall University, 2017, 2016.

29. Colt HG, Davoudi M, Quadrelli S. Pilot study of web-based bronchoscopy education using the Essential Bronchoscopist in Developing Countries (Mozambique and Mauritania). Respiration. 2007;74(3):358.

30. Bagayokoa C, Anneb A, Fieschi M, Geissbuhlera A. Can ICTs contribute to the efficiency and provide equitable access to the health care system in Sub-Saharan Africa? The Mali experience. Yearb Med Inform. 2011;20(01):33-8.

31. Adebola O, Lawson B. "The creation of a national telemedicine/ ehealth association in Nigeria and its impact on the Federal Ministry of Health ICT-committee." Telemed South Africa, 2006.

32. Mars M. Health capacity development through telemedicine in Africa. Yearb Med Inform. 2010;19(01):87-93.

33. Godstime JK, Odimayomi PK, Halilu SA. "Telemedicine development in Nigeria." National Space Research and Development Agency (NASRDA), Abuja-Nigeria, 2015.

34. Olayiwola JN, et al. Leveraging Electronic Consultations to Address Severe Subspecialty Care Access Gaps in Nigeria. J Natl Med Assoc. 2020;112(1):97-102.

35. Kennedy C, Bowman R, Fariza N, Ackuaku E, Ntim-Amponsah C, Murdoch I. Audit of Web-based telemedicine in ophthalmology. J Telemed Telecare. 2006;12(2):88-91.

36. Luk R, Zaharia M, Ho M, B. Levine B, Aoki PM. "ICTD for healthcare in Ghana: two parallel case studies," in 2009 international conference on information and communication technologies and development (ICTD). IEEE, 2009;118-128.

37. Yusif S, Jeffrey S. "Preparedness for e-Health in developing countries: the case of Ghana." J Health Informat Develop Countries, $2014 ; 8(2)$.

38. Nyame-Asiamah F. "Improving the 'manager-clinician'collaboration for effective healthcare ICT and telemedicine adoption processes-a cohered emergent perspective." Inform Technol Develop. 2019;1-26.

39. Tchao E, Acquah I, Kotey S, Aggor C, Kponyo J. On Telemedicine Implementations in Ghana. Int J Adv Comput Sci Appl. 2019;10(3):193-201.

40. Caumes E, Le Bris V, Couzigou C, Menard A, Janier M, Flahault A. Dermatoses associated with travel to Burkina Faso and diagnosed by means of teledermatology. Br J Dermatol. 2004;150(2):312-6.

41. Jacq F, et al. "Towards grid-enabled telemedicine in Africa," ISTAfrica Conference, Pretoria, South Africa. https://arxiv.org/abs/ physics/0605104v1, 2006.

42. Diallo AO, et al. "Development and implementation of a cloudbased meningitis surveillance and specimen tracking system in Burkina Faso, 2018." J Infect Dis. 2019;220(4):S198-S205.

43. Arnaert A, Ponzoni N, Debe Z, Meda MM, Nana NG, Arnaert $\mathrm{S}$. Experiences of women receiving mhealth-supported antenatal care in the village from community health workers in rural Burkina Faso, Africa. Digit Health. 2019;5:2055207619892756.

44. Mbarika VWA, Okoli C. "Telemedicine in sub-Saharan Africa: A proposed Delphi study." in 36th Annual Hawaii Intern Conf Syst Sci IEEE, 2003;9.

45. Geissbuhler A, Ly O, Lovis C, L'Haire JF. "Telemedicine in Western Africa: lessons learned from a pilot project in Mali, perspectives and recommendations." in AMIA Annual Symp Proc 2003 Am Med Informat Assoc. 2003;249.

46. Katzenstein J, Yrle AC, Chrispin B, Hartman S, Lundberg O. Telemedicine: An innovative technique in healthcare delivery. Acad Health Care Manag J. 2012;8(1/2):49.

47. Kingue $\mathrm{S}$, et al. "Efficiency of an intervention package for arterial hypertension comprising telemanagement in a Cameroonian rural setting: The TELEMED-CAM study." Pan African Med J. 2013;15(1). 
48. Qin R, Dzombak R, Amin R, Mehta K. Reliability of a telemedicine system designed for rural Kenya. J Prim Care Community Health. 2013;4(3):177-81.

49. Ferrari R, Amouzou KS, Gobitti C, Bartolo M. Teleoncology in sub-Saharan Africa: A literature review. J Cancer Policy. 2018;17:9-14.

50. Krüger C, Niemi M. A telemedicine network to support paediatric care in small hospitals in rural Tanzania. $\mathrm{J}$ Telemed Telecare. 2012;18(1):59-62.

51. Balogun O, Karamyan N, Formenti S, Brereton H, Botteghi M. Development and Implementation of a Telemedicine Platform for Radiation Oncology Training and Peer Review. J Global Oncol. 2018;4(2):91s-91s.

52. Nchise A, Boateng R, Mbarika V, Saiba E, Johnson O. The challenge of taking baby steps-Preliminary insights into telemedicine adoption in Rwanda. Health Policy Technol. 2012;1(4):207-13.

53. Murererehe J, Uwambaye P, Isyagi M, Nyandwi T, Njunwa K. Knowledge, attitude and practices of dental professionals in Rwanda towards the benefits and applications of teledentistry. Rwanda J. 2017;4(1):39-47.

54. Kabeza CB, Harst L, Schwarz PE, Timpel P. A qualitative study of users' experiences after 3 months: the first Rwandan diabetes self-management Smartphone application "Kir'App." Ther Adv Endocrinol Metab.2020;11:2042018820914510.

55. Bholah LA, Beharee K. "Mauritius eHealth-Trust in the healthcare revolution," in 2015 ITU Kaleidoscope: Trust in the Information Society (K-2015). IEEE, 2015;1-8.

56. Beebeejaun MR, Chittoo $\mathrm{H}$. An assessment of e-health readiness in the public health sector of Mauritius. Int J Sci Basic Appl Res. 2017;35(1):193-210.

57. Ratna CP, Juwaheer R, Pudaruth S. Assessing the Impact of Technology Adoption on Human Touch Aspects in Healthcare Settings in Mauritius. Studies Bus Econ.2018;13(2):164-78.

58. Gulube $S$, Wynchank $S$. Telemedicine in South Africa: success or failure? J Telemed Telecare. 2001;7(2):47-9.

59. Mars M. Telerehabilitation In South Africa-Is There A Way Forward? Int J Telerehabilitation. 2011;3(1):11.

60. Colven R, Shim M-HM, Brock D, Todd G. Dermatological diagnostic acumen improves with use of a simple telemedicine system for underserved areas of South Africa. Telemed E Health. 2011;17(5):363-9.

61. Littman-Quinn R, et al. "mHealth applications for telemedicine and public health intervention in Botswana" in 2011 IST-Africa Conference Proceedings IEEE. 2011;1-11.

62. Armstrong K, et al. Evaluation of txt2MEDLINE and development of short messaging service-optimized, clinical practice guidelines in Botswana. Telemed E Health. 2012;18(1):14-7.

63. Chang AY, et al. Use of mobile learning by resident physicians in Botswana. Telemed E Health. 2012;18(1):11-3.

64. Munyoka W. Evaluation impact of tele-education as new open distance learning delivery mode on Learners in Botswana. Procedia Soc Behav Sci. 2014;116:1248-52.

65. Chavez A, Littman-Quinn R, Ndlovu K, Kovarik CL. Using TV white space spectrum to practise telemedicine: A promising technology to enhance broadband internet connectivity within healthcare facilities in rural regions of developing countries. J Telemed Telecare. 2016;22(4):260-3.

66. Chandar A, et al. Building international partnerships to improve global oncological care: Perspective from RutgersCINJ Global Oncology Fellowship Program. J Clin Oncol. 2019;37(15):e18161-e18161.

67. Dinis M, Santiago F, Silva L, Ferreira R, Machado J, Castela E. Telemedicine as a tool for Europe-Africa cooperation: a practical experience. In: International Conference on e-Infrastructure and e-Services for Developing Countries. Springer; 2009. p. 86-94.

68. Bediang G, et al. The RAFT telemedicine network: lessons learnt and perspectives from a decade of educational and clinical services in low-and middle-incomes countries. Front Public Health. 2014;2:180.

69. Zennaro F, et al. "Digital radiology to improve the quality of care in countries with limited resources: a feasibility study from Angola." PloS One. 2013;8(9).

70. Correia JC, et al. "Implementation of a telemedicine network in Angola: challenges and opportunities." J Health Informat Develop Countries. 2017; 12(1).

Publisher's Note Springer Nature remains neutral with regard to jurisdictional claims in published maps and institutional affiliations. 